\title{
Punishment, Inequality, and the Future of Mass Incarceration
}

\author{
Bruce Western \& Christopher Wildeman*
}

The British sociologist, T.H. Marshall famously described citizenship as a "basic human equality associated with... full membership of a community." He went on to describe citizenship as "the architect of... social inequality." By this he meant that the inequalities that arise under particular institutions of citizenship appear natural and justified. Such inequalities are the immediate result of the rules of belonging to a given community. The injustice of such institutionalized inequalities runs counter to conventional intuitions, and remedies are difficult to conceive and implement.

Since the zenith of the Civil Rights Movement in the late 1960s, the character and extent of American citizenship have been redrawn by the steady growth in the penal population. The emergence of mass imprisonment-historically high and concentrated rates of incarceration-represents a new type of institutionalized inequality. As in Marshall's formulation, the inequality arising under these new rules of citizenship (to the extent it is visible at all) seems justified, delivering harsh punishment to those who flout the law.

In this Article, we trace the causes, contours, and consequences of the American prison boom. We argue that rapid growth in the penal system was fueled by a punitive turn in punishment and the deteriorating economic situation of black men and men with low levels of education. The explosion in prison and jail populations was felt most acutely by

Professor of Sociology and Director of the Multidisciplinary Program in Inequality and Social Policy at Harvard University, and Robert Wood Johnson Foundation Health \& Society Scholar and Postdoctoral Affiliate in the Population Studies Center at the University of Michigan, respectively. Professor Western is the author of Between Class and Market (1997) and Punishment and Inequality in America (2006). Christopher Wildeman will be an Assistant Professor of Sociology and Fellow in the Center for Research on Inequalities and the Life Course (CIQLE) at Yale University, starting in the 2010-2011 academic year. This research was supported by grants to Bruce Western from the National Science Foundation, the Russell Sage Foundation, and a Guggenheim Fellowship. Postdoctoral support was provided by the Robert Wood Johnson Foundation Health \& Society Scholars Program to Christopher Wildeman.

1. T.H. Marshall, Class, CitizEnShiP, AND SOCIAL DEVElopMENT 70 (1964).

2. Id. 
those who were already most disadvantaged — black men and men with low levels of educational attainment and their families. As a result, by the late 1990s, serving time in prison had become commonplace for young black men who had never been to college. For these same men's wives, girlfriends, and children, contact with the penal system has also become common in the last ten years.

Such inequalities are particularly fundamental. Their remedy may lie more in the social policies that can expand social citizenship than in one-time transfers, like reparations, or surface reforms of the justice system. We close by suggesting that a reversal of mass incarceration will involve changes in both criminal justice policy, and the broader social policy regime in which criminal justice is embedded. While recent developments in the area of prisoner reentry policy foreshadow a progressive current in criminal justice politics and policy, a retreat from mass incarceration will ultimately depend on the expansion of employment opportunities for low-skill men, and a reinvigoration of the moral status of these men in political debate. These political and economic developments remain well beyond the scope of criminal justice policy.

\section{THE POLITICAL AND ECONOMIC ROOTS OF THE PRISON BOOM ${ }^{3}$}

Mass imprisonment of the late 1990s can be traced to two basic shifts in politics and economics. The growth of harsh sentencing policies and a punitive approach to drug control began with a rightward shift in American politics, first visible at the national level in the mid-1960s. Barry Goldwater's fated presidential run in 1964 was pivotal. ${ }^{4}$ Goldwater, in accepting the Republican nomination, warned that crime and disorder were threats to human freedom and freedom must be "balanced so that liberty lacking order will not become the license of the mob and of the jungle." 5 The Republican campaign of 1964 linked the problem of street crime to civil rights protest and the growing unease among whites about racial violence. Although Goldwater was roundly defeated by Lyndon Johnson, conservatives within the Republican Party had brought to the national stage a new kind of politics. Historically,

3. Sections I-III are reprinted with permission from Bruce Western \& Christopher Wildeman, The Black Family and Mass Incarceration, 621 AnNAls OF THE AM. ACAD. POL. \& SOC. SCI. 221 (Jan. 2009). Some minor changes have been made to the text.

4. Ted Gest, Crime and Politics: Big Government's ERratic CAMPAign For LaW AND ORder 5 (2001); see KATHERINe BeCKetT, MAKING CRime PAY: LAW AND ORder IN CONTEMPORARY AMERICAN POLITICS 31 (1997).

5. William SAfire, Lend Me Your Ears: Great SpeECheS IN History 978 (2004). 
responsibilities for crime control were divided mostly between state and local agencies. The Republicans had placed the issue of crime squarely on the national agenda. What's more, by treating civil rights protest as a strain of social disorder, veiled connections were drawn between the crime problem on the one hand, and black social protest on the other.

The social problem of crime became a reality as rates of murder and other violence escalated in the decade following the 1964 election. Through the 1960s, urban riots in Los Angeles, New York, Newark, Detroit, and dozens of other cities provided a socially ambiguous mixture of disorder and politics. Despite Goldwater's defeat, support grew for the new law and order message, particularly among southern whites and northern working class voters of Irish, Italian, and German descent who turned away from the Democratic Party in the 1970s. ${ }^{6}$

Elevated crime rates and the realigned race relations of the post-Civil Rights period provided a receptive context for the law-and-order themes of the Republican Party. In state politics, Republican governors and legislators increased their representation through the South and West, and placed themselves in the vanguard of the movements for mandatory minimum sentences, sentence enhancements for repeat offenders, and expanded prison capacity. ${ }^{7}$ Quantitative analyses show that incarceration rates grew fastest under Republican governors and state legislators. ${ }^{8}$ Republicans were quick to promote prison expansion and tough new criminal sentences, but Democrats also came to support punitive criminal justice policy. Perhaps the clearest signal that Democrats too were tough on crime was sent by President Clinton's Violent Crime Control and Law Enforcement Act of 1994. The Clinton crime bill earmarked $\$ 9.9$ billion for prison construction and added life terms for third-time federal felons. ${ }^{9}$ By the 1990s, Democrats and Republicans had come to support the sentencing policies and capital construction campaigns that grew the penal population.

Shifts in politics and policy, however, are only half the story. The newly punitive system of criminal sentencing would have had largely symbolic significance, but for the ready supply of chronically idle young men that came to swell the nation's prisons and jails. Urban

6. Thomas Byrne Edsall \& Mary D. Edsall, Chain Reaction: The Impact of Race, RighTS, AND TAXES ON AMERICAN POLITICS (1991).

7. Joseph Dillon Davey, The Politics of Prison Expansion: Winning Elections by WAGING WAR ON CRIME (1998); BRUCE Western, PUnishment AND INEQUALITY IN AMERICA (2006); David Jacobs \& Jason T. Carmichael, The Politics of Punishment Across Time and Space: A Pooled Time-Series Analysis of Imprisonment Rates, 80 Soc. Forces 61 (2001).

8. WESTERN, supra note 7.

9. Lord Windelsham, Politics, Punishment, AND Populism (1998). 
deindustrialization eroded the labor market for unskilled young men while punitive politics gained momentum in the 1970s and 1980s. Wilson's study of The Truly Disadvantaged provides the classic analysis. ${ }^{10}$ The decline of manufacturing industry employment in the Midwest and the Northeast coupled with the exodus of the middle class and working class blacks from inner cities produced pockets of severe unemployment in poor urban neighborhoods. From 1969 to 1979, central cities recorded enormous declines in manufacturing and blue collar employment. New York, for example, lost 170,000 blue collar jobs through the 1970s, another 120,000 jobs were shed in Chicago, and blue collar employment in Detroit fell by 90,000 jobs. ${ }^{11}$ For young men in metropolitan areas, employment rates fell by thirty percent among black high school dropouts and nearly twenty percent among black high school graduates. ${ }^{12}$ Job loss was only a third as large among young noncollege whites. ${ }^{13}$

Variation in imprisonment is closely linked to variation in wages and employment. Weekly earnings for young low-education men declined through the 1980s and 1990s while imprisonment rates were rising. Among black men, unemployment increased steeply with declining education. One study estimates that if wages and employment had not declined among low-education men since the early 1980s, growth in prison admission rates would have been reduced by as much as twentyfive percent by $2001 .^{14}$

The urban deindustrialization that produced the raw material for the prison boom was as much a failure of institutions as a failure of markets. Large job losses in the mid-1970s and early 1980s were concentrated in unionized industries. ${ }^{15}$ Deunionization thus joined manufacturing decline to drive down the incomes of unskilled inner city workers. Besides unemployment insurance, which provided only temporary assistance, few social programs were available to supplement the incomes, retrain, or mobilize young able-bodied men into new jobs. The

10. William Julius Wilson, The Truly Disadvantaged: The InNer City, the UNDERCLASS, AND PUBLIC POLICY (1987).

11. John D. Kasarda, Urban Industrial Transition and the Underclass, 501 ANNALS OF THE AM. ACAD. POL. \& SOC. SCI. 26, 29 (Jan. 1998).

12. John Bound \& Harry J. Holzer, Industrial Shifts, Skills Levels, and the Labor Market for White and Black Males, 75 REV. ECON. \& STAT. 387, 390 (1993).

13. Id.

14. Bruce Western, Meredith Kleykamp, \& Jake Rosenfeld, Crime, Punishment, and American Inequality, in SOCIAL INEQUALITY 771 (Kathryn M. Neckerman ed., 2004).

15. See generally Henry S. Farber \& Bruce Western, Accounting for the Decline of Unions in the Private Sector, 1973-1998, 22 J. LAB. RES. 459 (2001). 
welfare system was also poorly-equipped to handle the social problems linked to male unemployment. Drug addiction, petty offending, and public idleness all afflicted the neighborhoods of concentrated disadvantage.

Idle young men in poor minority neighborhoods supplied a large share of the inmates that drove the prison boom. The path from concentrated economic disadvantage to mass imprisonment runs partly through the mechanism of crime, but policy also played a vital role. At any given point in time, crime among young disadvantaged men is higher than in the rest of the population. For example, the victimization and offending rates for murder are about twenty-five times higher for black men aged eighteen to twenty-four than for white men aged twenty-five and older. ${ }^{16}$ Violent crime is also a more serious problem in poor communities than affluent communities. ${ }^{17}$ The criminal involvement of young, economically disadvantaged men makes them more likely at a given point in time to go to prison than others who are less involved in crime. Crime cannot explain, however, why disadvantaged young men were so much more likely to go to prison by the end of the 1990 s than two decades earlier. Indeed, survey data show that poor male youth were much less involved in crime at the height of the prison boom, in 2000, than at its inception in 1980. To explain the growing risk of imprisonment over time, the role of policy is decisive. Because the system of criminal sentencing had come to rely so heavily on incarceration, an arrest in the late 1990s was far more likely to lead to prison time than at the beginning of the prison boom in $1980 .{ }^{18}$

The drug trade holds a special place in this story. The drug trade itself became a source of economic opportunity in the jobless ghetto. Ethnographers paint striking pictures of how the inner-city drug trade becomes a focal point for the problems of economic disadvantage, violence, and state control. Sudhir Venkatesh and Steven Levitt describe how drug trafficking thrived in the vacuum of legitimate employment in Chicago's southside neighborhoods. ${ }^{19}$ Chicago youth spoke to Venkatesh and Levitt "of their gang affiliation and their drive to earn

16. Sourcebook of Criminal Justice Statistics 309-10 (Ann L. Pastore \& Kathleen Maguire eds., 2004), available at http://www.albany.edu/sourcebook/pdf/section3.pdf.

17. John Braithwaite, Inequality, Crime, and Public Policy 58-59 (1979). See generally Robert J. Sampson, Urban Black Violence: The Effect of Male Joblessness and Family Disruption, 93 AM. J. SoC. 348 (1987).

18. Alfred Blumstein \& Allen J. Beck, Population Growth in U.S. Prisons, 1980-1996, in 26 CRIME \& JUST. 17 (Michael Tonry \& Joan Petersilia eds., 1999).

19. Sudhir Alladi Venkatesh \& Steven D. Levitt, "Are We a Family or a Business?" History and Disjuncture in the Urban American Street Gang, 29 THEORY \& SOC'Y 427 (2000). 
income in ways that resonated with representations of work in the mainstream corporate firm. Many approached [gang] involvement as an institutionalized path of socioeconomic mobility for down-and-out youth....,20 In Elijah Anderson's account, violence follows the drug trade as crime becomes a voracious force in the poor neighborhoods of Philadelphia:

Surrounded by violence and by indifference to the innocent victims of drug dealers and users alike, the decent people are finding it harder and harder to maintain a sense of community. Thus violence comes to regulate life in the drug-infested neighborhoods and the putative neighborhood leaders are increasingly the people who control the violence. $^{21}$

The picture drawn by the ethnographic research is of poor neighborhoods, chronically short of legitimate work and embedded in a violent and illegal market for drugs.

High rates of joblessness and crime and a flourishing street trade in illegal drugs combined with harsher criminal penalties and intensified urban policing to produce high incarceration rates among young unskilled men in inner cities. In the twenty-five years following 1980, the incarceration rate tripled among white men in their twenties, but fewer than two percent were behind bars by 2004. Imprisonment rates for young black men increased less quickly, but one in seven were in custody by 2004. Incarceration rates are much higher among male high school dropouts in their twenties. Threefold growth in the imprisonment of young white male dropouts left seven percent in prison or jail by 2004 . The incarceration rate for young low-education black men rose by twenty-two points in the two decades after 1980. Incredibly, thirty-four percent of all young black male high school dropouts were in prison or jail on an average day in 2004, an incarceration rate forty times higher than the national average.

Tough sentences for drug and repeat offenders, strict policing and prosecution of drug traffic and public order offending, and unforgiving parole supervision broadened the use of imprisonment from its traditional focus on serious crime. Certainly sentences increased for serious crime, and this contributed to incarceration rates too. For example, time served for murderers increased from five to eleven years

20. Id. at 447 .

21. Elijah Anderson, Code of the Street: DeCency, Violence, AND the Moral Life of THE INNER CITY 134 (1999). 
from 1980 to $1996 .^{22}$ But growth in the share of less serious offenders in state prison increased much more rapidly. ${ }^{23}$ Growth in the numbers of drug offenders, parole violators, and public order offenders reflects the use of penal policy as a surrogate social policy, in which a troublesome and unruly population is increasingly managed with incarceration.

\section{MASS INCARCERATION}

The scale of the penal system is usually measured by an incarceration rate. The incarceration rate records the number of people in prison or jail on a given day per 100,000 of the population. Figure 1 compares the U.S. incarceration rate in 2004 to the incarceration rates of the longstanding democracies of Western Europe. The penal systems of Western Europe locked up, on average, about 100 per 100,000. The United States by contrast incarcerated more than seven times the European average, with an incarceration rate of around 725 per 100,000.

22. Blumstein \& Beck, supra note 18 , at 36 .

23. Id. at 24,37 . 
Figure 1: 2004 Incarceration Rates per 100,000 Residents: United States and Western Europe ${ }^{24}$

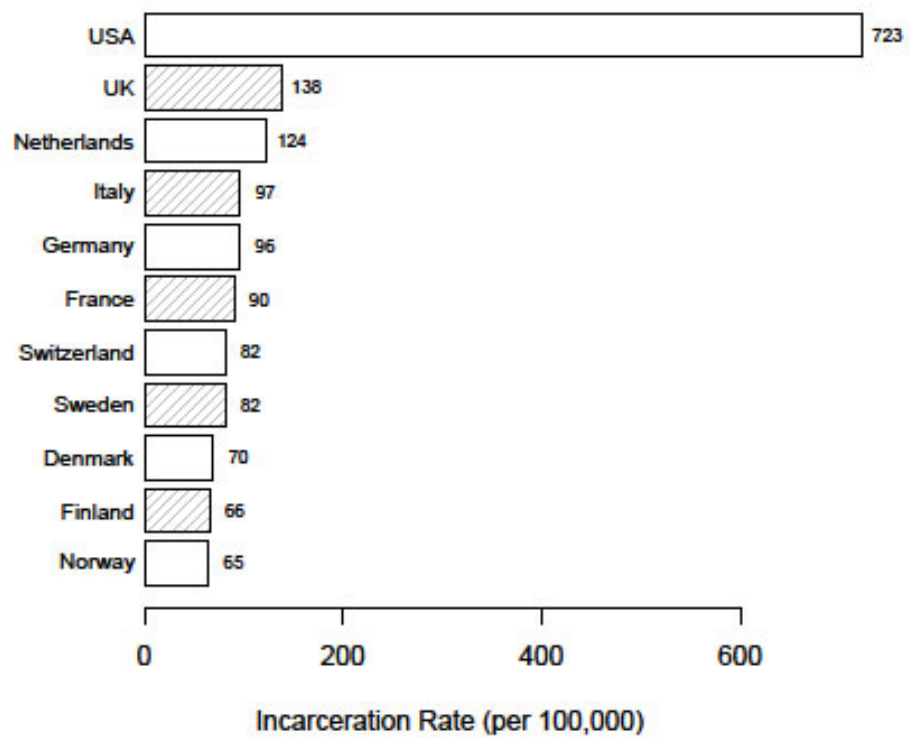

The contemporary scale of criminal punishment is also historically unusual. Although we do not have long time series of the total penal population of prison and jail inmates, there are data on the state and federal prison populations extending back to 1925 . The time series in Figure 2 shows that between 1925 and 1973, the fraction of the U.S. population in state and federal prison varied in a narrow range around 100 per 100,000 - close to the total incarceration rates in Western Europe. From 1974, the prison population began to grow, and the incarceration rate increased continuously for the next three decades. By 2005, nearly 2.2 million people were in custody, either in prison for felony convictions, or in local jails awaiting trial or serving short sentences. These figures do not fully reflect the contemporary correctional population. In 2005, another 784,000 men and women were under community supervision on parole while 4.1 million people were on

24. Marcelo F. Aebi, Council of Europe, 14th Conference of Directors of Prison Administration: Council of Europe Annual Penal Statistics-2006 Survey (Nov. 19, 2007), available at http://www.coe.int/t/e/legal_co_operation/prisons_and_alternatives/conferences/cdap\%20(2007) $\% 2021 \% 20-\% 20$ (Aebi\%20SPACE).pdf. 
probation. The total population under correctional supervision thus includes more than 7.1 million people, or about $3.1 \%$ of all U.S. adults. ${ }^{25}$

Figure 2: U.S. State and Federal Imprisonment Rates, 1925-2007; U.S. Prison and Jail Incarceration Rates, 1983-2005 26

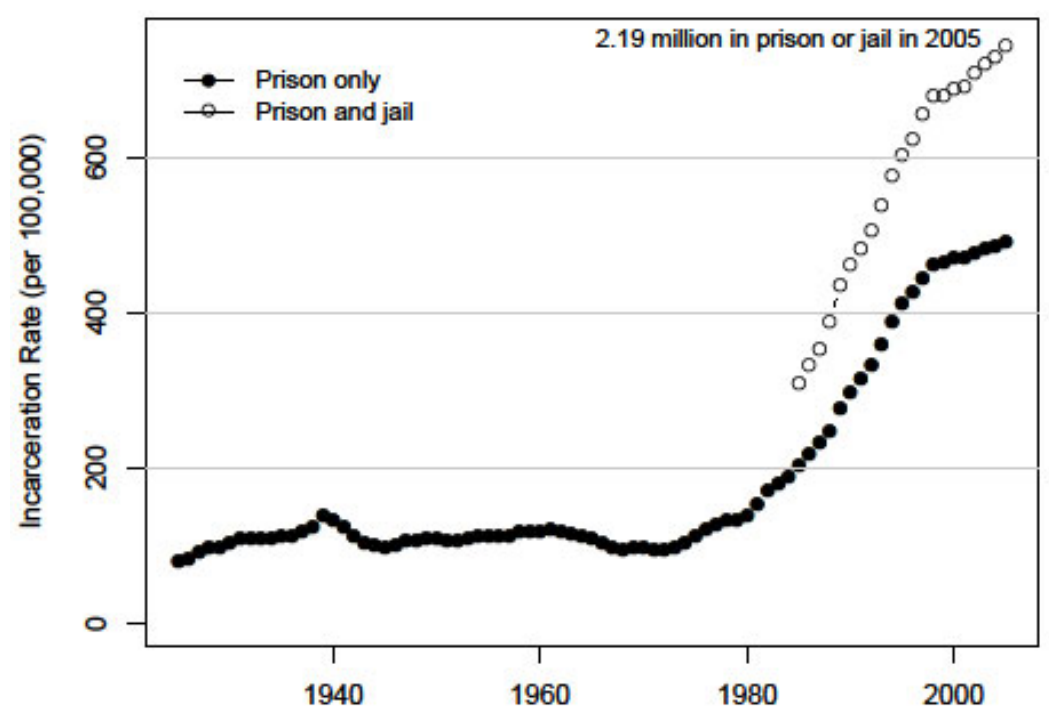

The broad significance of the penal system for American social inequality results from extreme social and economic disparities in incarceration. More than ninety percent of all prison and jail inmates are men. Women's incarceration rates have increased more quickly than men's since 1980, but much higher rates persist for men, leaving women to contend with raising children while their partners cycle in and out of jail. These men are young, of working age, and many with small

25. Lauren E. Glaze \& Thomas P. Bonczar, Bureau of Justice Statistics, Probation AND PAROle in the United States, 2007 Statistical TABles (2008), available at http://www.jp.usdoj.gov/bjs/pub/pdf/ppus07st.pdf; WILLIAM J. SABOL ET AL., BUREAU OF JUSTICE Statistics Bulletin, PRison AND Jail InMATes AT Midyear 2006 (2007), available at http://www.ojp.usdoj.gov/bjs/pub/pdf/pjim06.pdf.

26. William J. Sabol \& Heather Couture, Bureau of Justice Statistics, Prison INMATES AT MIDYEAR 2007 (2008), available at http://www.ojp.usdoj.gov/bjs/pub/pdf/pim07.pdf; Sourcebook of Criminal Justice Statistics (Anne L. Pastore \& Kathleen Maguire eds., 2007), available at $\mathrm{http}: / / \mathrm{www} . a l b a n y . e d u /$ sourcebook/pdf/section3.pdf. 
children. About two-thirds of state prisoners are over eighteen years old but under age thirty-five. With this age pattern, only a small number of people are incarcerated at any point in time, but many more pass through the penal system at some point in their lives.

Incarceration is also concentrated among the disadvantaged. High incarceration rates among low-status and minority men are unmistakable. The 2004 survey of state and federal prisoners shows that state inmates average less than eleven years of schooling. A third were not working at the time of their incarceration, and the average wage of the remainder is much lower than that of other men with the same level of education. Blacks and Hispanics also have higher incarceration rates than whites. Blacks and Hispanics together account for about two-thirds of the state prison population.

The black-white difference in incarceration rates is especially striking. Black men are eight times more likely to be incarcerated than whites and large racial disparities can be seen for all age groups and at different levels of education. The large black-white disparity in incarceration is unmatched by most other social indicators. Racial disparities in unemployment (2 to 1), nonmarital childbearing (3 to 1 ), infant mortality ( 2 to 1 ), and wealth (1 to 5) are all significantly lower than the 8 to 1 black-white ratio in incarceration rates. If white men were incarcerated at the same rate as blacks there would be over six million people in prison and jail, and the incarceration rate would include more than five percent of the male working-age population. ${ }^{27}$

"Age, race, and educational disparities concentrate imprisonment among the disadvantaged." ${ }^{28}$ From 1980 to 2004, the percentage of young white men in prison or jail increased from $0.6 \%$ to $1.9 \%{ }^{29}$ Among young white men with only a high school education, incarceration rates were about twice as high. ${ }^{30}$ At the dawn of the prison boom, in 1980, the incarceration rate for young black men at $5.7 \%$ was more than twice as high as that for low education whites. By 2004, $13.5 \%$ of black men in their twenties were in prison or jail. Incarceration rates were higher in the lower half of the education distribution. More than one in five young non-college black men were behind bars on a typical day in 2004.

Incarceration rates offer a snapshot of the extent of penal confinement. Time series of incarceration rates tell us how the extent of

\footnotetext{
27. WESTERN, supra note 7 , at 16.

28. Id.

29. Id.

30. Id. at 17.
} 
penal confinement has shifted historically. We can also study, not the level of incarceration at a point in time, but how the risk of incarceration accumulates over an individual's life. This kind of life course analysis asks what is the likelihood an individual will go to prison by age twentyfive, thirty, or thirty-five. Instead of providing a snapshot of the risk of incarceration, this analysis describes a typical biography.

The life course perspective provides a compelling account of social integration. In this account, the passage to adulthood is a sequence of well-ordered stages that affect life trajectories long after the early transitions are completed. In modern times, arriving at adult status involves moving from school to work, then to marriage, then to establishing a home and becoming a parent. Completing this sequence without delay promotes stable employment, marriage, and other positive life outcomes. The process of becoming an adult thus influences success in fulfilling adult roles and responsibilities.

As an account of social integration, life course analysis has attracted the interest of students of crime and deviance. Criminologists point to the normalizing effects of life course transitions. Steady jobs and good marriages build social bonds that keep would-be offenders in a daily routine. ${ }^{31}$ They enmesh men who are tempted by crime in a web of supportive social relationships. ${ }^{32}$ Strong family bonds and steady work restrict men's opportunities for antisocial behavior and offer them a stake in normal life. ${ }^{33}$ For persistent law-breakers, the adult roles of spouse and worker offer a pathway out of crime. ${ }^{34}$ Those who fail to secure the markers of adulthood are more likely to persist in criminal behavior. This idea of a normalizing, integrative, life path offers a powerful alternative to claims that criminality is a stable trait possessed by some, but absent in others. Above all else, the life course account of crime is dynamic, describing how people change as their social context evolves with age.

Imprisonment significantly alters the life course. Working life is disrupted as workers with prison records try to find jobs from employers who are deeply suspicious of applicants with criminal records. The stigma of a prison record also creates legal barriers to skilled and

31. Robert J. SAMPSON \& John H. LAUB, CRime IN THE MAKING: PATHWAYS AND TURNing Points Through Life 141 (1993); John Hagan, The Social Embeddedness of Crime and Unemployment, 31 CRIMINOLOGY 465, 471-72 (1993); Mark Warr, Life-Course Transitions and Desistance from Crime, 36 CRIMINOLOGY 183, 187 (1998).

32. See sources cited supra note 31 .

33. See id.

34. See id. 
licensed occupations, rights to welfare benefits, and voting rights. ${ }^{35}$ Exprisoners are also less likely to get married or cohabit with the mothers of their children. ${ }^{36}$ By eroding opportunities for employment and marriage, incarceration may also lead ex-inmates back to a life of crime. The volatility of adolescence may last well into mid-life for men serving prison time. In short, imprisonment is a turning point in which young crime-involved men acquire a new status involving diminished life chances.

To place the risks of imprisonment in the context of the life course, we report estimates of the cumulative risks of imprisonment by age thirty to thirty-four, for five year birth cohorts born through the postwar period. Because most inmates enter prison for the first time before age thirtyfive, these cumulative risks of imprisonment roughly describe lifetime risks of imprisonment. We emphasize that these lifetime risks of incarceration are for imprisonment, as opposed to jail incarceration. Imprisonment here describes a sentence of twelve months or longer for a felony conviction, now about twenty-eight months of time served, at the median. 
Table 1: Cumulative Risk of Imprisonment by Age 30-34 by Race and Education for Men Born 1945-1949 to 1975-1979 ${ }^{37}$

\begin{tabular}{llllllll}
\hline & \multicolumn{7}{c}{ Birth Cohort } \\
\cline { 2 - 8 } & $45-$ & $50-$ & $55-$ & $60-$ & $65-$ & $70-$ & $75-$ \\
& 49 & 54 & 59 & 64 & 69 & 74 & 79 \\
\cline { 2 - 8 } $\begin{array}{llllllll}\text { White Men } \\
\quad \text { High School }\end{array}$ & 4.2 & 7.2 & 8.0 & 8.0 & 10.5 & 14.8 & 15.3 \\
$\begin{array}{l}\text { Dropouts } \\
\text { High School }\end{array}$ & 0.7 & 2.0 & 2.1 & 2.5 & 4.0 & 3.8 & 4.1 \\
$\begin{array}{l}\text { Only } \\
\text { All Non-College }\end{array}$ & 1.8 & 2.9 & 3.2 & 3.7 & 5.1 & 5.1 & 6.3 \\
$\quad \begin{array}{l}\text { Some College } \\
\text { All Men }\end{array}$ & 0.7 & 0.7 & 0.6 & 0.8 & 0.7 & 0.9 & 1.2 \\
& 1.2 & 1.9 & 2.0 & 2.2 & 2.8 & 2.8 & 3.3 \\
Black Men & & & & & & & \\
$\quad$ High School & 14.7 & 19.6 & 27.6 & 41.6 & 57.0 & 62.5 & 69.0 \\
$\begin{array}{l}\text { Dropouts } \\
\text { High School }\end{array}$ & 10.2 & 11.3 & 9.4 & 12.4 & 16.8 & 20.3 & 18.0 \\
Only & & & & & & & \\
All Non-College & 12.1 & 14.1 & 14.7 & 19.9 & 26.7 & 30.9 & 35.7 \\
Some College & 4.9 & 3.5 & 4.3 & 5.5 & 6.8 & 8.5 & 7.6 \\
All Men & 9.0 & 10.6 & 11.5 & 15.2 & 20.3 & 22.8 & 20.7 \\
\hline
\end{tabular}

The oldest cohort was born just after World War Two and reached their mid-thirties in 1979, just at the take-off of the prison boom. In this group, just over one percent of whites and nine percent of blacks would go to prison. As incarceration rates climbed through the 1980s, lifetime imprisonment risks also increased. The big jump in imprisonment separates men born in the 1950s and earlier from those born in the 1960s and later. The pervasive presence of the criminal justice system in the lives of black men only emerges among those born since the mid-1960s, who are reaching their mid-thirties from the end of the 1990s. Like the long time series of incarceration rates, these figures on postwar birth cohorts underscore the historic novelty of mass incarceration. Only through the 1990s, did the penal system figure prominently in the lives of young black men.

37. Data sources and methods are described in Becky Pettit \& Bruce Western, Mass Imprisonment and the Life Course: Race and Class Inequality in U.S. Incarceration, 69 AM. SoC. REV. 151 (2004). Estimates for the cohorts born after 1969 are based on data from the 2004 Survey on Inmates of States and Federal Correctional Facilities. 
Like incarceration rates, lifetime risks of imprisonment are also steeply stratified by education. We report cumulative risks of imprisonment for men who have had at least some college education and for all those with just a high school education. Among those with just a high school education, we separate high school dropouts and high school graduates. We report figures for all non-college men becauseparticularly for blacks - those without college education have remained an approximately constant proportion of the population. Educational attainment has increased across birth cohorts chiefly because the proportion of high school dropouts has declined.

Lifetime risks of imprisonment among black men with little schooling are particularly striking. For non-college black men, about twelve percent of those born just after the War would ultimately go to prison. For those born thirty years later, reaching their thirties in 2005, at least thirty-six percent would serve prison time. ${ }^{38}$ At the very bottom of the education distribution, among high school dropouts, prison time has become extraordinarily prevalent. For black male dropouts born since the mid-1960s, sixty to seventy percent go to prison. For this very poorly schooled segment of the population, serving time in prison has become a routine life event on the pathway through adulthood. Indeed we need only go back several decades to find a time when incarceration was not pervasive in the lives of young black men with little schooling.

Detailed figures on the racial and educational differences in imprisonment also show another pattern. While lifetime risks of imprisonment grew three-fold for men without a college education, imprisonment among the college-educated less than doubled. In short, most of the growth in imprisonment was concentrated among those with little schooling. At the same time racial disparities in imprisonment risks, while large, did not increase significantly. The figures thus indicate that in the period of the prison boom, class inequality in incarceration clearly increased, but racial inequality did not. Because racial disparities in imprisonment were so large to begin with, however, the prison boom produced extraordinarily high rates of incarceration among young non-college black men.

38. This is actually a slight under-estimate, because those born between 1975 and 1979 have not been exposed to the risk of imprisonment for as long as the older cohorts. 
Table 2: Percentage of Non-Hispanic Black and White Men, Born 19651969, Experiencing Life Events by $1999^{39}$

\begin{tabular}{lrr}
\hline \multicolumn{1}{c}{ Life Event } & Whites & Blacks \\
\hline & & \\
All Men & 3.2 & 22.4 \\
Prison Incarceration & 31.6 & 12.5 \\
Bachelor's Degree & 14.0 & 17.4 \\
Military Service & 72.5 & 59.3 \\
Marriage & & \\
Non-College Men & 6.0 & 31.9 \\
Prison Incarceration & 73.5 & 64.4 \\
High School & & \\
$\quad$ Diploma/GED & 13.0 & 13.7 \\
Military Service & 72.8 & 55.9 \\
Marriage &
\end{tabular}

From a life course perspective we can compare imprisonment to other significant life events that are commonly thought to mark the path through young adulthood. Life course researchers have previously studied college graduation, military service, and marriage as key milestones that move young men forward in life to establishing a household and a steady job. Comparing imprisonment to these life events suggests how the pathway through adulthood has been changed by the prison boom. The risks of each life event are different for blacks and whites, but racial differences in imprisonment greatly overshadow any other inequality. Whites by their early thirties are more than twice as likely to hold a bachelor's degree than blacks. Blacks are about fifty percent more likely to have served in the military. However, black men in their early thirties are about seven times more likely than whites to have a prison record. Indeed, recent birth cohorts of black men are more likely to have prison records $(22.4 \%)$ than military records $(17.4 \%)$ or bachelor's degrees $(12.5 \%)$. The share of the population with prison records is particularly striking among non-college men. Whereas few non-college white men have prison records, nearly a third of black men with less than a college education have been to prison. Non-college

39. The incidence of all life events except prison incarceration were calculated from the 2000 Census. To make the incarceration risks comparable to Census statistics, the estimates are adjusted to describe the percentage of men, born 1965-1969, who have ever been imprisoned and survived to 1999. Pettit \& Western, supra note 37. 
black men in their early thirties in 1999 were more than twice as likely to be ex-felons than veterans. By 1999 imprisonment had become a common life event for black men that sharply distinguished their pathway through adulthood from that of white men.

David Garland coined the term "mass imprisonment" to refer to the high rate of incarceration in the contemporary United States. In Garland's definition, mass imprisonment has two characteristics. First, "[m]ass imprisonment implies a rate of imprisonment. . . that is markedly above the historical and comparative norm for societies of this type." by the late 1990s was far higher than in Western Europe and without precedent in U.S. history. Second, Garland argues, the demographic concentration of imprisonment produces not the incarceration of individual offenders, but the "systematic imprisonment of whole groups of the population." 41 The empirical markers of mass imprisonment are more slippery in this case.

When will the incarceration rate be high enough to imprison not the individual but the group? The picture painted by the statistics in this paper helps us answer this question. Not only did incarceration become common among young black men at the end of the 1990s, its prevalence exceeded that of other life events that we usually associate with passage through the life course. More than college graduation or military service, incarceration typified the biographies of black men born since the late 1960s.

\section{MASS INCARCERATION AND FAMILY LIFE}

As imprisonment became common for low-education black men by the end of the 1990s, the penal system also became familiar to poor minority families. By 1999, thirty percent of non-college black men in their mid-thirties had been to prison and, through incarceration, many were separated from their wives, girlfriends, and children. Women and children in low-income urban communities now routinely cope with absent husbands and fathers lost to incarceration and adjust to their return after release. Poor single men detached from family life are also affected, bearing the stigma of a prison record in the marriage markets of disadvantaged urban neighborhoods.

\footnotetext{
40. David Garland, Introduction to MASS IMPRISONMENT: SOCIAL CAUSES AND CONSEQuences 1, 1 (David Garland ed., 2001).

41. Id. at 2 .
} 
Discussions of the family life of criminal offenders typically focus on the crime-suppressing effects of marriage, not the effects of incarceration on family life. Researchers find that marriage offers a pathway out of crime for men with histories of delinquency. Not a wedding itself, but marriage in the context of a warm, stable, and constructive relationship offers the antidote to crime. ${ }^{42}$ Wives and family members in such relationships provide the web of obligations and responsibilities that restrain young men and reduce their contact with the male friends whose recreations veer into anti-social behavior. ${ }^{43}$ The prison boom places the link between crime and marriage in a new light. If a good marriage is important for criminal desistance, what is the effect of incarceration on marriage?

The connections between incarceration, marriage, and the family are also implicated in the larger story of rising urban inequality. In the last three decades, American family life was transformed by declining marriage rates and growth in the number of single-parent households. Marriage rates fell among women from all class backgrounds. Between 1970 and 2000, the share of white women aged twenty-five to thirty-four who were married declined from over eighty percent to just over sixty percent. Marriage rates for black women halved from sixty to around thirty percent. The decline in marriage propelled growth in the number of single-parent households, although this effect was confined to those with little education. ${ }^{44}$ The share of college-educated women who were single mothers remained constant at around five percent between 1970 and 2000, while the fraction of single mothers among low-education white women increased from eight to eighteen percent. Trends were most dramatic among black women. In 1970, about one-third of loweducation black women were single parents, but the number increased to over fifty percent in the next thirty years. By 2000, stable two-parent households became relatively rare, especially among blacks with little schooling.

Poverty researchers closely followed the changing shape of American families. Growing numbers of female-headed families increased the risks of enduring poverty for women and children.

42. See John H. Laub et al., Trajectories of Change in Criminal Offending: Good Marriages and the Desistance Process, 63 AM. Soc. ReV. 225 (1998); SAMPSON \& LAUB, supra note 31, at 205-09, 211-14, 217-20, 224-25, 227-28, 232-42.

43. Warr, supra note 31 , at $188-96$ (positing that marriage disrupts or dissolves friendships that existed prior to marriage, including relationships with criminal offenders).

44. David T. Ellwood \& Christopher Jencks, The Uneven Spread of Single-Parent

Families: What Do We Know? Where Do We Look For Answers?, in SocIAL InEQuality, supra note 14 , at 3 . 
Growing up poor also raised a child's risk of school failure, poor health, and delinquency. Writing in the mid-1980s, William Julius Wilson traced the growth in the number of female-headed black families to the shrinking number of "marriageable men" in poor urban areas. ${ }^{45}$ The shortage of suitable husbands in ghetto neighborhoods was driven by two processes. High rates of male incarceration and mortality tilted the gender ratio, making it harder for poor urban women to find partners. These effects were small, however, compared to the high rate of joblessness that left few black men in inner cities able to support a family. Many studies later examined the impact of men's employment on marriage rates and found that the unemployed are less likely to be married and that joblessness can increase chances of divorce or separation. ${ }^{46}$ Studies of the effects of employment dominated research on marriage among the disadvantaged, and the idea that incarceration destabilized family life was undeveloped.

To study the family ties of prisoners, we begin by simply describing the levels of marriage and fatherhood in the penal population. Figure 3 compares rates of marriage and fatherhood in the penal population to those for men who are not incarcerated. Levels of marriage are measured for non-institutional men and male prison and jail inmates, aged twenty-two to thirty, in 2000. Rates of fatherhood are the percentage of non-institutional men and male state prisoners, aged thirtythree to forty, who have ever had children by 1997-1998.

Marriage rates among prison and jail inmates are very low compared to those on the outside. White male inmates in their twenties are less than half as likely to be married as young white non-institutional men of the same age. The incarceration gap in marriage is also large for black and Hispanic men. The general level of marriage is highest for Hispanics, but in this case, inmates are only half as likely to be married as their counterparts in the non-institutional population. Although marriage rates are lowest for black men, only eleven percent of young black inmates are married compared to a marriage rate of twenty-five percent among young black men outside of prison and jail. In short, marriage rates among male prisoners in their twenties are only around

45. See WiLSON, supra note 10, at 91 ("[B]lack women, especially young black women, are facing a shrinking pool of 'marriageable' (i.e., economically stable) men.").

46. E.g., Francine D. Blau et al., Understanding Young Women's Marriage Decisions: The Role of Labor and Marriage Market Conditions, 53 Indus. \& LAB. ReL. ReV. 624 (2000); Daniel T. Lichter et al., Local Marriage Markets and the Marital Behavior of Black and White Women, 96 AM. J. Soc. 843 (1991); Sara McLanahan \& Lynne Casper, Growing Diversity and Inequality in the American Family, in 2 STATE OF THE UnION, AMERICA IN THE 1990s: Social TRENDS 1 (Reynolds Farley ed., 1995). 
half as high as in the free population.

Figure 3: The Percentage of Men, Aged 22-30, Who Are Married in 2000 and Men, Aged 33-40, Who Are Fathers by 1997-1998. ${ }^{47}$

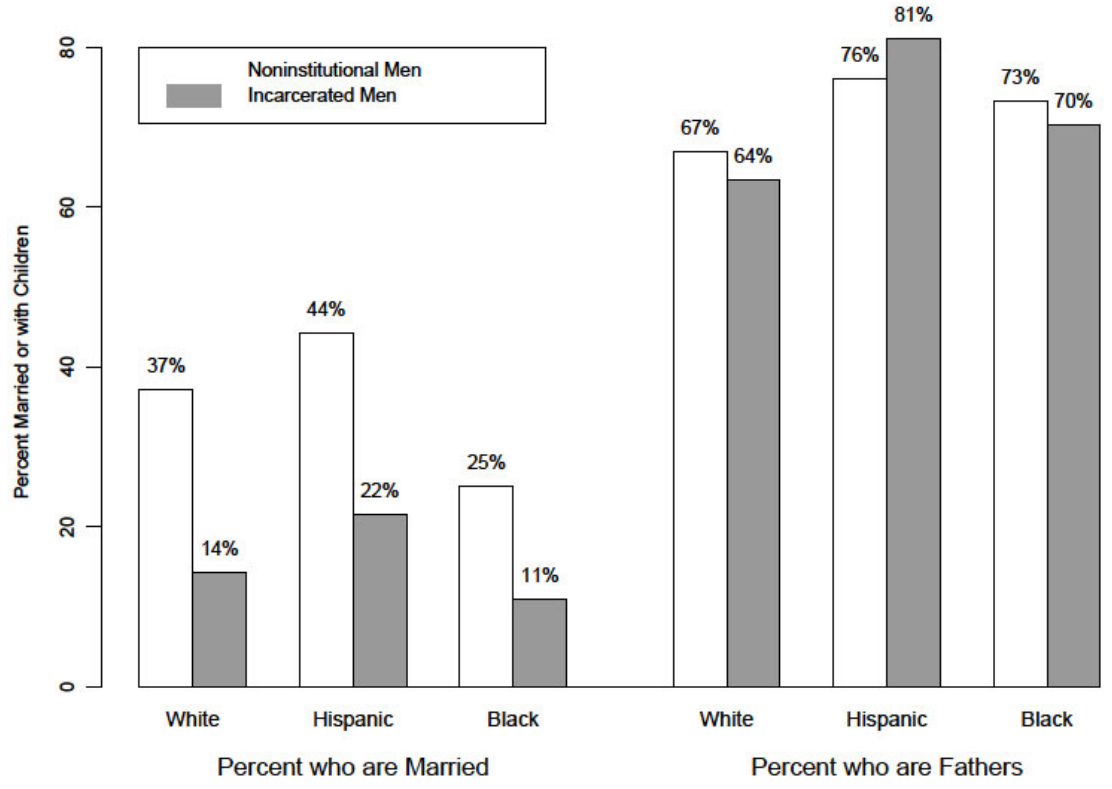

Although marriage is uncommon among prisoners, they are just as likely as other men to have children. Figure 3 shows the percentage of men who have ever had children by their late thirties. The prevalence of fatherhood among prisoners is almost identical to that on the outside. For example, seventy-three percent of non-institutional black men have had children by their late thirties compared to seventy percent of black male prisoners of the same age. Male fertility rates among prisoners and nonprisoners are also very similar for whites and Hispanics.

The combination of high incarceration rates with a large proportion of fathers among inmates means many children now have incarcerated fathers. Data from surveys of prison and jail inmates can be used to calculate the numbers of children with fathers in prison or jail. A time series for 1980 to 2000 shows that the total number of children with incarcerated fathers increased sixfold from about 350,000 to 2.1 million, 
nearly $3 \%$ of all children nationwide in 2000 . Among whites, the fraction of children with a father in prison or jail is relatively smallabout $1.2 \%$ in 2000 . The figure is about three times higher $(3.5 \%)$ for Hispanics. Among blacks, over a million, or one in eleven, black children had a father in prison or jail in 2000. The numbers are higher for younger children: by $2000,10.4 \%$ of black children under age ten had a father in prison or jail. Just as incarceration has become a normal life event for disadvantaged young black men, parental incarceration has become commonplace for their children.

To better gauge the impact of mass incarceration on children, we report the cumulative risks that one of their parents will be sent to prison. We also report these risks of parental incarceration for black and white children of parents at different levels of education. Just as lifetime risks of imprisonment help describe the life course of adults, cumulative risks of parental imprisonment tell us about the early life course of children.

These figures include incarceration among mothers as well as fathers. The rapid growth in incarceration among women is reflected in these figures. Although incarceration rates among mothers are much lower than those for fathers, the effects of maternal imprisonment on parental separation from children are relatively large. Whereas just under half of fathers were living with their children at the time they were sent to prison, nearly two-thirds of mothers sent to prison were living with their children. ${ }^{48}$

Table 3 reports the risks of parental imprisonment by age fourteen for children born in 1978 and $1990 .^{49}$ Among white children born in 1978 who reached their teenage years in the early 1990s, around two percent experienced a parent being sent to prison. Among black children born in the same year, around fourteen percent had a parent sent to prison by age fifteen. Twelve years later, among children born in 1990, about a quarter of all black children had a parent sent to prison. Indeed, the proportion of black children who had a mother sent to prison (a relatively rare event) nearly equaled the proportion of white children who had a father sent to prison.

48. Christopher J. Mumola, Bureau of Justice Statistics, InCArcerated Parents and THEIR CHILDREN 3 (2000).

49. Christopher Wildeman, Parental Imprisonment, the Prison Boom, and the Concentration of Childhood Disadvantage, DEMOGRAPHY (forthcoming 2009). 
Table 3: Cumulative Risks of Paternal and Maternal Imprisonment for Children Born in 1978 and 1990, by Parent's Race and Education ${ }^{50}$

\begin{tabular}{lcccc} 
& \multicolumn{2}{c}{ Whites } & \multicolumn{2}{c}{ Blacks } \\
& Maternal & Paternal & Maternal & Paternal \\
\hline Born 1978 & & & & \\
$\quad$ All & 0.2 & 2.1 & 1.4 & 13.4 \\
$\quad$ High School & 0.2 & 4.0 & 1.9 & 21.4 \\
$\quad$ Dropout & & & & \\
$\quad$ High School & 0.2 & 2.0 & 0.9 & 9.9 \\
$\quad$ Graduate & & & & \\
$\quad$ All Non-College & 0.2 & 2.8 & 1.5 & 15.1 \\
Some College & 0.2 & 1.4 & 1.2 & 7.1 \\
& & & & \\
Born 1990 & & & & \\
$\quad$ All & 0.6 & 3.6 & 3.2 & 24.5 \\
$\quad$ High School & 1.0 & 7.1 & 5.0 & 49.4 \\
$\quad \begin{array}{l}\text { Dropout } \\
\text { High School }\end{array}$ & 0.7 & 4.7 & 2.6 & 20.0 \\
$\quad$ Graduate & & & & \\
$\quad \begin{array}{l}\text { All Non-College } \\
\text { Some College }\end{array}$ & 0.8 & 5.5 & 3.6 & 24.5 \\
& 0.3 & 1.7 & 2.6 & 13.2 \\
\hline
\end{tabular}

The children of low-education parents were far more exposed to the criminal justice system than the population in general. These estimates indicate that among children born in the late 1970s with non-college black parents, about one in seven had a parent sent to prison by the time they reached their teenage years. Just over a decade later, over a quarter of the children of non-college black parents experienced parental imprisonment. For black children whose parents dropped out of high school, around half had a parent sent to prison by the early 2000s. Just as imprisonment had become a normal life event for young black male dropouts, so had parental imprisonment become normal for their children.

The prevalence of marriage and fatherhood among prison and jail inmates tells us something about the incapacitation effect of incarceration. Men behind bars cannot fully play the role of father and husband. Single incarcerated men are unlikely to get married while they

50. Sources, methods, and figures are reported in Wildeman, supra note 49. 
are locked up. On the outside, the incapacitation effect takes the form of lopsided gender ratios of poor communities. For example, in the highincarceration neighborhoods of Washington D.C. there are only sixtytwo men for every hundred women. ${ }^{51}$ Studying U.S. counties, William Sabol and James Lynch quantify the effects of the removal of men to prison. ${ }^{52}$ After accounting for educational attainment, welfare receipt, poverty, employment and crime, Sabol and Lynch found that the doubling of the number of black men admitted to prison between 1980 and 1990 was associated with a nineteen percent increase in the number of families headed by black women. ${ }^{53}$

The incapacitation effect captures only part of the impact of the prison boom on marriage. In Wilson's terms, incarceration also damages men's marriageability. Wilson traced declining marriage rates among the ghetto poor to the increasing inability of young disadvantaged black men to support families. ${ }^{54}$ Incarceration erodes men's economic desirability even more. Incarceration reduces men's wages, slows the rate of wage growth, increases unemployment, and shortens job tenure. If a poor employment record damages the marriage prospects of single men and contributes to the risk of divorce among those who are married, the economic effects of incarceration will decrease the likelihood of marriage among men who have been to prison and jail.

Wilson measured marriageability mostly by employment, but a man's criminal record also signals his ability to care for and provide for his family. While poor women care about men's economic status, they also worry about men's honesty and respectability. Edin's ethnographic interviews showed that these non-economic concerns weighed heavily on low-income women in metropolitan Philadelphia. ${ }^{55}$ The women Edin interviewed were deeply distrustful of men. The respondents were often reluctant to marry or develop romantic relationships because they viewed men's marital infidelity as inevitable. ${ }^{56}$ Some women's trust in men was shaken by boyfriends who spent household savings on drugs or drink,

51. Donald Braman, Doing Time on the OUtSide: InCARCERATION AND FAMily Life IN URBAN AMERICA 85 (2004).

52. William J. Sabol \& James P. Lynch, Assessing the Longer-Run Consequences of Incarceration: Effects on Families and Unemployment, in CRIME CONTROL AND SOCIAL JUSTICE: The DeliCATE BALANCE 3 (Darnell F. Hawkins et al. eds., 2003).

53. Id. at 17 .

54. WiLSON, supra note 10, at 83-92.

55. Kathryn Edin, Few Good Men: Why Poor Mothers Don't Marry or Remarry, THE AMERICAN PROSPECT, Jan. 3, 2000, at 26.

56. Id. at 29 . 
and neglected children in their care. ${ }^{57}$ This wariness was compounded by the men's low social status. For the women in Edin's sample, marriage offered a route to respectability, but "[m]arriage to an economically unproductive male means ... permanently taking on his very low status." 58 Elijah Anderson makes a similar point in the opposite way, describing the dreams of teenage girls in ghetto neighborhoods as a dream of "living happily ever after with one's children in a nice house in a good neighborhood - essentially the dream of the middle-class American lifestyle." ${ }^{59}$ In these cases, it is the social status of jobless men, their lack of esteem, as much as their material resources, that limits their appeal as husbands.

If reliability and reputation measure the non-economic aspects of marriageability, incarceration has likely eroded the pool of marriageable men. Just as the stigma of incarceration confers disadvantage in the labor market, it also undermines a man's prospects in the marriage market. Men in trouble with the authorities cannot offer the respectability that many poor women seek from their partners. A prison record - the official stamp of criminality - can convey trouble to mothers looking for a stable home. For example, Edin's interviews described women's aversion to drug dealing, even when it provided a couple with income: "Mothers fear that if their man gets involved in drug dealing, he might stash weapons, drugs, or drug proceeds in the household, that the violence of street life might follow him into the household. ${ }^{\circ 6}$ Because marriage offers a way of enhancing status, the trouble foreshadowed by a prison record may be even more repellent than chronic unemployment.

The stigma of incarceration also strains existing relationships. Erving Goffman describes stigma's contagious quality, suffusing personal relationships: "In general, the tendency for a stigma to spread from the stigmatized individual to his close connections provides a reason why such relations tend either to be avoided or to be terminated, where existing." ${ }^{61}$ Braman's fieldwork in Washington D.C. provides empirical support. The high prevalence of incarceration, he finds, does little to reduce its stigmatic effect. ${ }^{62}$ Braman describes the experience of Louisa, whose husband Robert was arrested on an old armed robbery

57. Id. at 30 .

58. Id. at 29 .

59. ANDERSON, supra note 21, at 151

60. Edin, supra note 55, at 28 (citations omitted).

61. ERving Goffman, Stigma: Notes on the Management of Spoiled Identity 30 (1963).

62. Braman, supra note 51, at 165-67. 
charge after a lengthy period out of prison and in recovery from drug addiction. The couple:

had come to think of and present themselves as morally upstanding citizens and churchgoers. Because of this, Louisa felt the stigma of her husband's most recent incarceration all the more intensely. She began to avoid friends and family, not wanting to talk about Robert's incarceration and lying to them when she did. ${ }^{63}$

Louisa came to withdraw from her extended family and grappled with depression during Robert's incarceration. ${ }^{64}$ Braman argues that the stigma of incarceration is even more severe for family members than the offender, because wives and children live and work outside the prison, exposed to the condemnation of neighbors and other community members.

The separation imposed by incarceration also weighs heavily on relationships. Interviews with ex-offenders suggest that the friendships that underlie romantic relationships are diluted by time apart. Often women become more independent and self-sufficient while their partners are incarcerated. ${ }^{65}$ Just as Edin's female respondents distrusted men's commitment, Anne Nurse reports that her Californian sample of juvenile offenders were constantly suspicious of the fidelity of their wives and girlfriends. ${ }^{66}$ Often these fears were well-founded and many romantic relationships failed while men were still incarcerated. ${ }^{67}$

Quantitative analysis of survey data is generally consistent with the field research. Black single men are especially likely to remain unmarried if they have prison records. The gap in marriage rates between black non-inmates and ex-inmates is estimated to be anywhere from twenty to two hundred percent. Survey data point more strongly to the destabilizing effects of incarceration on couples. Consider an analysis of the Fragile Families Survey of Child Wellbeing - a survey of mostly poor urban couples with infant children. The survey shows that men who are living with the mothers of their newborn children are three times more likely to separate within the year if they have a history of incarceration. ${ }^{68}$

63. Id. at 170 .

64. Id.

65. Ann M. Nurse, Fatherhood Arrested: Parenting from Within the Juvenile JUSTICE SYSTEM 109 (2002).

66. Id. at 57-61.

67. See also Edin, supra note 55, at 28 (discussing how poor mothers react when the child's father is incarcerated).

68. WESTERN, supra note 7, at 131-67. 


\section{CONCLUSION: THE FUTURE OF MASS INCARCERATION}

By the beginning of this decade, the family life of poor blacks in urban neighborhoods of concentrated poverty had become strained by mass incarceration. Young black men who had never been to college were now routinely going to prison. Family disruption and children's experience with parental incarceration had become similarly commonplace.

Growth in the American penal population amounted to a redrawing of the rules of citizenship. "Full membership in the community," in T.H. Marshall's phrase, was denied to those who carried the stigma of a prison record. ${ }^{69}$ Facing an array of diminished life chances and a social experience wholly outside of the mainstream of American life, the formerly incarcerated and their families occupy a second-class position in which racial and class disadvantage congeals into an inferior social status.

How might mass incarceration be reversed? Reducing prison populations is so far barely on the agenda of elected officials, and its specter carries great political risk. Still, state budgets are stressed by correctional expenditures, and social supports for prisoners reentering society has been a lively area of activity for city governments and local non-profit organizations. Some states too are reconsidering their most draconian drug sentencing laws. Thus there are faint signs that the tough-on-crime movement has lost a little of its momentum.

While an expanded reentry policy and a revision of the penal codes may stop the growth of prisons and jails, the future of mass incarceration depends very much on its past. A less punitive criminal justice system cannot by itself solve the deep social problems of poor urban neighborhoods. These problems - of disorder and addiction largely flowing from chronic idleness - set in motion the politics and policy choices that delivered mass incarceration. As America's meager welfare state failed to prevent school dropout and chronic unemployment among unskilled inner-city residents, prisons and jails expanded to fill the vacuum of social control formerly occupied by the education system and the labor market. Police, courts, and correctional administrators were charged to solve the social problems of idleness, addiction, and mental illness, while also controlling their natural jurisdiction over serious crime. But they were given only a few tools: the powers of arrest and imprisonment. Mass incarceration contained an unruly population beset

69. MARSHALL, supra note 1 , at 70 . 
with trouble; wholesale confinement made the population more manageable but left their troubles undiminished.

To expect a rehabilitative criminal justice system by itself to reverse mass incarceration would, in an odd way, repeat the mistakes of the tough-on-crime movement. We would again be turning to line officers to manage the by-products of deep social inequalities. While we might spend billions on a jobs program for former prisoners, we would still send them out to look for work in labor markets where half the young men are jobless, while staying sober amid a thriving street trade in illegal drugs. Prisoners understand this when they say they are set up to fail. This is not just a recidivist's special pleading; it reflects the deficiencies of a theory in which society's losers have only themselves to blame.

Reversing mass incarceration will ultimately require that social problems be solved with social policies. The two most urgent priorities are the prevention of school dropout and the creation of a viable and legitimate economy in poor inner-city neighborhoods. Not even the most rehabilitative criminal justice policy can by itself solve these problems. We normally think of education and employment as sources of economic opportunity. In the era of mass incarceration we also see that they are positive sources of social control, providing order in people's daily lives.

In sum, just as mass incarceration has diminished the quality of American citizenship and created a second-class status among poor black families, an expansion of social citizenship can redress the balance. The political will for such an effort will likely lie in universalistic policies that aim to raise the social standard for all, rather than just for the most disadvantaged. Universal provision - and the bonds of citizenship on which it is built-joins us to a common destiny and might be the best chance for the redevelopment of urban schools and labor markets. If the duty of the citizen is to stay in school and go to work, then the political will to maintain good schools and promote employment is woven into the social fabric. This political logic implies that special projects that target special populations will not do the job. If poor schools are to improve, it is more likely to result from a national effort to improve educational opportunity across the board. If we are to promote jobs for unskilled men in the inner-city, such an effort will receive the greatest impetus from a national employment policy that aims to improve the working lives of all citizens. Clearly, we are not there yet. The norms of good citizenship, however, develop in tandem with the institutions of civic life. Political will can grow in small increments led by the promotion of institutions that provide on the basis of what T.H. Marshall called our basic human equality. Such a renewal of an authentically 
American social citizenship would sweep away the jobless ghetto and the mass incarceration that it spawned. 